Volume 11, Nomor 2, November 2019, pp 276-288 Copyright (C) 2017 Jurnal Akuntansi Maranatha, Program Studi Akuntansi, Fakultas Ekonomi, Universitas Kristen Maranatha. ISSN 2085-8698 | e-ISSN 2598-4977. http://journal.maranatha.edu

\title{
Analisis Laporan Akuntabilitas Kinerja Instansi Pemerintahan Dinas Kebudayaan, Pariwisata, Pemuda dan Olahraga Kabupaten Kubu Raya
}

\author{
Beby Nurtesha Putri \\ Fakultas Ekonomi Program Studi Magister Manajemen Universitas Katolik Parahyangan \\ (Jl. Merdeka No.30, Bandung) \\ beby.prilly@rocketmail.com
}

\begin{abstract}
The purpose of this study was to find out about performance measurement in the Department of Culture, Tourism, Youth and Sports of Kubu Raya Regency. Performance measurement is carried out by the Government Agency Performance Accountability Report in accordance with Presidential Instruction No. 7 of 1999. Performance measurement is used as a basis for assessing failure program efficacy and execution and activities according to targets and objectives set in realizing the vision and mission of the Regency Government. The research method used in this research is descriptive method. Data obtained, then interpreted and analyzed, so that it can provide information that can be used to solve the problem at hand. The type of data used is secondary and primary data. The results of the study show performance for all existing targets and in accordance with the expected conditions. Suggestions the government needs to establish a standard reference in preparing reports.
\end{abstract}

Keywords: Accountability, Agency Performance Accountability Report

\section{Pendahuluan}

Laporan Akuntabilitas Kinerja Instansi Pemerintah atau LAKIP adalah media akuntabilitas kinerja yang dapat dipakai oleh instansi pemerintah untuk melaksanakan kewajiban dan sebagai bahan pelaporan kepada pihak-pihak yang berkepentingan. Media akuntabilitas yang dibuat secara periodik memuat informasi yang dibutuhkan oleh pihak yang memberi amanah atau pihak yang memberikan delegasi wewenang. Melalui media secara formal dapat dilakukan pertanggungjawaban dan bahan untuk menjawab berbagai permasalahan yang diminta oleh pihak-pihak yang berkepentingan untuk menentukan fokus perbaikan kinerja yang berkesinambungan.

LAKIP yang selama ini disusun dan disajikan secara terpisah dengan laporan keuangan, harus disusun dan disajikan secara terintegrasi dengan laporan keuangan, sehingga dapat memberi 
informasi yang komprehensif berkaitan dengan keuangan dan kinerja. Dalam rangka perwujudan dan pertanggungjawaban pelaksanaan tugas pokok dan fungsi serta pengelolaan sumber daya pelaksanaan kebijakan dan program yang dipercayakan kepada setiap instansi pemerintah, berdasarkan suatu sistem akuntabilitas yang memadai. Dalam hal ini, pemerintah secara periodik wajib mengkomunikasikan pencapaian tujuan dan sasaran strategis organisasi kepada pihakpihak yang berkepentingan yang dituangkan dalam LAKIP.

Dinas Kebudayaan, Pariwisata, Pemuda dan Olahraga Kabupaten Kubu Raya mengacu pada instruksi Presiden nomor 7 tahun 1999 tentang Akuntabilitas Kinerja Instansi Pemerintah dan peraturan pemerintah nomor 108 tahun 2001 tentang tata cara pertanggungjawaban kepala daerah. Maka visi, misi dan tujuan organisasi atau Instansi Pemerintah dipertanggungjawabkan secara transparan dan dinilai berdasarkan tolak ukur Rencana Strategis (Renstra). Tujuan penyusunan dan penyampaian LAKIP adalah untuk mewujudkan akuntabilitas instansi pemerintah kepada pihak-pihak yang memberi amanat.

Menurut Santoso (2013) penyusunan LAKIP kepada pihak yang berhak (secara hierarki) juga bertujuan untuk memenuhi antara lain:

a. Pertanggungjawaban dari unit yang lebih rendah ke unit yang lebih tinggi atau pertanggungjawaban dari bawahan kepada atasan.

b. Pengambilan keputusan dan pelaksanaan perubahan-perubahan kearah perbaikan, dalam mencapai efisiensi dan efektifitas pelaksana tugas pokok dan fungsi, serta ketaatan terhadap peraturan perundangundangan yang berlaku dalam rangka pelaksanaan misi instansi.

c. Perbaikan dalam perencanaan khususnya jangka menengah dan jangka pendek.
Laporan Akuntabilitas Kinerja ini mengkomunikasikan pencapaian kinerja instansi pemerintah pada periode tertentu. Capaian kinerja (performance result) pada suatu periode diperbandingkan dengan rencana kinerja (performance plan) pada periode yang sama maka hasilnya dapat dijadikan tolak ukur keberhasilan/ kegagalan pada periode tersebut. Analisis atas capaian kinerja terhadap rencana kinerja ini akan memungkinkan di identifikasi bagi perbaikan kinerja di masa yang akan datang.

Dinas Kebudayaan, Pariwisata, Pemuda dan Olahraga Kabupaten Kubu Raya telah merumuskan sasaran yang ingin dicapai secara bertahap sampai akhir 2013 adalah sebagai berikut:

a. Meningkatkan profesionalisme dan akuntabilitas aparatur.

b. Berkembangnya seni dan kebudayaan daerah.

c. Meningkatnya sosialisasi dan promosi kekayaan budaya daerah.

d. Terciptanya masyarakat yang mempunyai partisipasi yang tinggi untuk mengembangkan dan melestarikan budaya daerah.

e. Terbangunnya kemitraan pengelolaan kekayaan budaya antar daerah.

f. Terbangunnya fasilitas kebudayaan daerah.

g. Berkembangnya pemasaran pariwisata.

h. Berkembangnya destinasi pariwisata.

i. Berkembangnya/terbangunnya kemitraan.

j. Meningkatkan pembinaan organisasi kepemudaan.

k. Meningkatnya keterlibatan pemuda dalam kegiatan kepemudaan.

1. Meningkatnya jiwa kepemimpinan dan kepeloporan dikalangan pemuda.

m. Terjaringnya bakat dan potensi pelajar di cabang olahraga tertentu.

n. Terdatanya olahraga unggulan di 9 kecamatan. 
o. Terjadinya kerjasama dengan instansi lain dalam rangka pemberian penghargaan kepada atlet.

p. Terbinanya atlet pemula hasil identifikasi bakat dan potensi pelajar.

q. Terbinanya olahraga unggulan di kecamatan maupun kabupaten.

r. Terbinanya atlet berprestasi hasil kompetisi tingkat kabupaten maupun provinsi baik pelajar maupun kejurda.

Dari kedelapan belas sasaran tersebut telah dirumuskan sasaran strategis Dinas Kebudayaan, Pariwisata, Pemuda dan Olahraga Kabupaten Kubu Raya, yaitu:

a. Jumlah penyelenggaraan festival seni dan budaya.

b. Jumlah sarana penyelenggaraan seni dan budaya.

c. Jumlah benda, situs dan kawasan cagar budaya yang dilestarikan.

d. Presentase sanggar seni yang aktif.

e. Presentase situs budaya yang terpelihara.

f. Jumlah kunjungan wisatawan (domestik).

g. Jumlah kunjungan wisatawan (asing).

h. Presentase kontribusi sektor pariwisata terhadap PDRB.

i. Presentase tingkat hunian hotel.

j. Rasio destinasi wisata unggulan.

k. Jumlah gelanggang/balai remaja (selain milik swasta) per 1.000 penduduk.

1. Jumlah lapangan olahraga per 1.000 penduduk.

m. Jumlah kegiatan pembinaan pemuda.

n. Jumlah event olahraga tingkat kabupaten yang diselenggarakan.

o. Jumlah event olahraga tingkat regional yang diikuti.

p. Jumlah event olahraga tingkat nasional yang diikuti di kabupaten.

q. Pembinaan olahraga kepada pembina keolahragaan di kabupaten.

r. Jumlah kelompok kewirausahaan pemuda

s. Jumlah siswa berprestasi di bidang olahraga t. Presentase guru olahraga latar belakang olahraga.

u. Presentase olahraga rekreasi yang dikembangkan.

v. Presentase olahraga prestasi yang berprestasi.

Sebagai aktualisasi dalam pencapaian sasaran strategis tersebut, maka dalam kurun waktu 5 tahun (2009-2014), sedang dan akan dilaksanakan 9 program utama, lebih lanjut dalam pelaksanaan 9 program utama tersebut, dijabarkan dalam bentuk kegiatan-kegiatan yang dialokasikan dalam periode tahun 2009-2014.

Anggaran yang di dapat oleh Dinas Kebudayaan, Pariwisata, Pemuda dan Olahraga Kabupaten Kubu Raya yaitu:

Tabel 1

Pendapatan Dinas BUDPARPORA Kabupaten Kubu Raya

\begin{tabular}{|l|l|}
\hline Tahun & Pendapatan \\
\hline 2011 & Rp 5.714.240.996,00 \\
\hline 2012 & $\operatorname{Rp~6.143.562.447,00}$ \\
\hline 2013 & $\operatorname{Rp~6.310.961.650,00~}$ \\
\hline \\
$\begin{array}{l}\text { Sumber: Dinas BUDPARPORA } \\
\text { Kabupaten Kubu Raya }\end{array}$
\end{tabular}

\section{Rumusan Permasalahan}

Berdasarkan latar belakang yang telah dipaparkan rumusan masalahnya adalah:

Bagaimana tingkat keberhasilan atau kegagalan pelaksanaan tugas dan fungsi pokok Dinas Kebudayaan, Pariwisata, Pemuda dan Olahraga Kabupaten Kubu Raya berdasarkan Laporan Akuntabilitas Kinerja Pemerintah (LAKIP)?

\section{Kerangka Teoritis}

\section{Akuntansi Sektor Publik}

Bastian (2010) mendefinisikan akuntansi sektor publik sebagai mekanisme teknis dan analisis akuntansi yang diterapkan pada pengelolaan dana masyarakat di lembaga- 
lembaga tinggi negara dan departemendepartemen di bawahnya, pemerintah daerah, BUMN, BUMD, LSM dan yayasan sosial, maupun pada proyek-proyek kerjasama sektor publik dan swasta. Nordiawan (2006) menyatakan akuntansi sektor publik adalah proses pencatatan, pengklasifikasian, penganalisisan dan pelaporan transaksi keuangan dari suatu organisasi publik yang menyediakan informasi keuangan bagi para pemakai laporan keuangan yang berguna untuk pengambilan keputusan. Secara umum akuntansi sektor publik adalah sistem akuntansi yang dipakai oleh lembagalembaga publik sebagai salah satu alat pertanggungjawaban kepada publik. Dewasa ini terdapat perhatian yang makin besar terhadap praktek akuntansi yang dilakukan oleh lembaga-lembaga publik, baik akuntansi sektor pemerintahan maupun lembaga publik non-pemerintah. Lembaga publik mendapat tuntutan dari masyarakat untuk dikelola secara transparan dan bertanggungjawab. Sektor publik adalah manajemen keuangan yang berasal dari publik sehingga menimbulkan konsekuensi untuk dipertanggungjawabkan kepada publik. Dengan demikian pengelolaannya memerlukan keterbukaan dan akuntabilitas terhadap publik.

Ruang lingkup akuntansi sektor publik meliputi badan-badan pemerintahan yaitu pemerintah pusat, pemerintah daerah, dan unit-unit kerja pemerintah, organisasi sukarelawan, rumah sakit, perguruan tinggi dan universitas, yayasan, lembaga swadaya masyarakat, organisasi keagamaan, organisasi politik, dan sebagainya.

Sistem akuntansi untuk badanbadan pemerintahan harus mengikuti standar akuntansi pemerintah (SAP) seperti dimaksud dalam undang-undang nomor 17 tahun 2003 pasal 32, undang-undang nomor 1 tahun 2004 pasal 51 ayat 3 , dan peraturan pemerintah nomor 24 tahun 2005. Di sisi lain, unit-unit pemerintah yang bergerak di bidang bisnis (BUMN dan BUMD) harus mengikuti standar akuntansi keuangan yang dikeluarkan oleh IAI (Ikatan Akuntansi Indonesia). Sementara itu, organisasi publik non-pemerintahan mengikuti standar akuntansi keuangan.

Tujuan sektor publik adalah memberi pelayanan kepada masyarakat dan mensejahterakan masyarakat, misalnya pelayanan dalam bidang pendidikan, keamanan, kesehatan masyarakat, penegakan hukum, transportasi publik, penyediaan barang kebutuhan masyarakat dan sebagainya. Sementara itu, sektor komersial bertujuan mencari laba untuk meningkatkan kesejahteraan pemegang saham.

Sektor publik memperoleh biaya dari pajak, retribusi, laba BUMN dan BUMD, pinjaman luar negeri, obligasi, sumbangan, dana abadi, hibah, dan lainnya. Sedangkan sektor komersial memperoleh biaya dari modal pemilik dan laba yang ditahan, utang bank, obligasi, dan penerbitan saham baru.

Sektor publik dan sektor komersial memiliki persamaan, dimana keduanya adalah bagian yang saling berhubungan dari sistem ekonomi negara, dan sumber daya yang sama untuk mencapai tujuan organisasi. Keduanya juga menghadapi masalah yang sama yaitu kelangkaan sumber daya sehingga harus menggunakannya secara efektif dan efisien. Selain itu, keduanya memiliki manajemen yang sama, produk yang sama, dan samasama terikat pada aturan yang berlaku.

\section{Akuntabilitas}

Dalam definisi tradisional, akuntabilitas adalah istilah umum untuk menjelaskan sejumlah organisasi telah memperlihatkan bahwa mereka telah memenuhi misi yang mereka jalani (Benveniste:1991) dalam jurnal Reformasi Birokrasi Publik Dalam Persepektif Good Governance. Dalam pengertian luas, akuntabilitas dapat dipahami sebagai kewajiban pihak pemegang amanah (agent) untuk memberikan pertanggungjawaban, menyajikan, melaporkan, dan 
mengungkapkan segala aktivitas dan kegiatan yang menjadi tanggung jawabnya kepada pihak pemberi amanah (principal) yang memiliki hak dan kewenangan untuk meminta pertanggungjawaban tersebut. Selain itu pada Deklarasi Tokyo mengenai petunjuk akuntabilitas publik menetapkan pengertian akuntabilitas yakni kewajibankewajiban dari individu-individu atau penguasa yang dipercayakan untuk mengelola sumber-sumber daya publik dan yang bersangkutan dengannya untuk dapat menjawab hal-hal yang menyangkut pertanggungjawaban fiskal, manajerial dan program.

\section{Kinerja}

Banyak pendapat yang mengungkapkan tentang kinerja diantaranya menurut Anwar Prabu Mangkunegara (2013) "Kinerja ( prestasi kerja) adalah hasil kerja secara kualitas dan kuantitas yang dicapai oleh seseorang pegawai dalam melaksanakan tugasnya sesuai dengan tanggung jawab yang diberikan kepadanya". Selain itu menurut Ambar Teguh dan Rosidah (2009) Kinerja seseorang merupakan kombinasi dari kemampuan, usaha dan kesempatan yang dapat dinilai dari hasil kerjanya. Pendapat lain yang juga mengemukakan tentang kinerja yaitu mengemukakan bahwa individu yang memiliki kinerja yang tinggi memiliki beberapa karakteristik, yaitu diantaranya: (a) ber-orientasi pada prestasi, (b) memiliki percaya diri, (c) berpengendalian diri, (d) kompetensi.

Pada dasarnya kinerja itu adalah merupakan jawaban dari berhasil atau tidaknya tujuan organisasi yang telah ditetapkan. Kinerja itu dapat terjadi tentu saja didasari oleh beberapa faktor yang melatarbelakanginya menurut Robert L. Mathis dan John H. Jackson (2011) faktorfaktor yang memengaruhi kinerja individu tenaga kerja, yaitu kemampuan mereka, motivasi, dukungan yang diterima, keberadaan pekerjaan yang mereka lakukan, dan hubungan mereka dengan organisasi.

\section{Pengukuran Kinerja Organisasi Sektor Publik}

Sistem pengukuran kinerja sektor publik adalah suatu sistem yang bertujuan untuk membantu manajer publik menilai pencapaian suatu strategi melalui alat ukur finansial dan non finansial. Sistem pengukuran kinerja dapat dijadikan sebagai alat pengendalian organisasi, karena pengukuran kinerja diperkuat dengan menetapkan reward and punishment system. Maksud dilakukannya pengukuran kinerja sektor publik (Mardiasmo 2011):

1. Membantu memperbaiki kinerja pemerintah.

2. Pengalokasian sumber daya dan pembuatan keputusan.

3. Mewujudkan pertanggungjawaban publik dan memperbaiki komunikasi kelembagaan.

Pengukuran kinerja dilakukan dengan mengembangkan variabel kunci yang sudah teridentifikasi menjadi indikator kinerja. Indikator kinerja dapat berbentuk faktor keberhasilan utama organisasi dan indikator kunci. Indikator kinerja penting untuk mengetahui apakah aktivitas atau program telah dilakukan secara efisien dan efektif.

Komponen yang digunakan dalam penentuan indikator kinerja:

1. Biaya pelayanan (cost of service)

Indikator biasanya diukur dalam bentuk biaya unit.

2. Penggunaan (utilization)

Indikator penggunaan membandingkan antara supply of service (pelayanan yang ditawarkan) dengan public demand (permintaan publik).

3. Kualitas dan standar pelayanan (quality and standards);

Indikator kualitas dan standar pelayanan merupakan indikator yang paling sulit diukur.

4. Cakupan pelayanan (coverage), indikator cakupan pelayanan perlu dipertimbangkan apabila terdapat kebijakan atau peraturan perundangan yang mensyaratkan untuk memberikan 
pelayanan dengan tingkat pelayanan minimal yang telah ditetapkan.

5. Kepuasan (satisfaction), indikator kepuasan biasanya diukur melalui metode jajak pendapat secara langsung.

\section{Laporan Akuntabilitas Kinerja Instansi Pemerintahan (LAKIP)}

LAKIP atau Laporan Akuntabilitas Kinerja Instansi Pemerintah adalah media akuntabilitas yang dapat dipakai oleh instansi pemerintah untuk melaksanakan kewajiban untuk menjawab kepada pihakpihak yang berkepentingan (stakeholder).

Pentingnya LAKIP bermanfaat bagi dilaksanakannya Evaluasi Kinerja. Fungsi Laporan Akuntabilitas Kinerja Instansi Pemerintah (LAKIP), antara lain:

1. Media hubungan kerja organisasi

2. Media akuntabilitas

3. Media informasi umpan balik perbaikan kinerja

4. LAKIP sebagai instrumen peningkatan kinerja berkesinambungan seperti:

a. Action, artinya LAKIP sebagai bahan untuk perbaikan kelembagaan, ketatalaksanaan, peningkatan sumber daya manusia, akuntabilitas dan pelayanan publik.

b. Plan, artinya LAKIP sebagai sebagai bahan dalam menyusun Renstra, Rencana Kerja Tahunan, Penetapan Kinerja untuk tahun yang akan datang.

c. Check, maksudnya LAKIP dapat digunakan untuk mengevaluasi keberhasilan atau kegagalan dalam pencapaian tujuan dan sasaran organisasi.

d. Do, artinya LAKIP sebagai alat dalam melaksanakan, memantau, mengukur kinerja kegiatan suatu instansi.

LAKIP yang disampaikan oleh instansi pemerintah bermanfaat sebagai:

1. Meningkatkan akuntabilitas

Kredibilitas instansi di mata instansi yang lebih tinggi dan akhirnya meningkatkan

kepercayaan

masyarakat terhadap instansi.

2. Umpan balik untuk peningkatan kinerja instansi pemerintah, antara lain melalui perbaikan penerapan fungsi-fungsi manajemen secara benar, mulai dari perencanaan kinerja hingga kepada evaluasi kinerja, serta pengembangan nilainilai akuntabilitas di lingkungan instansi tersebut.

3. Mengetahui dan menilai keberhasilan dan kegagalan dalam melaksanakan tugas dan tanggung jawab instansi;

4. Mendorong instansi pemerintah untuk menyelenggarakan tugas umum pemerintahan dan pembangunan secara baik, sesuai ketentuan peraturan perundangundangan yang berlaku, kebijakan yang transparan dan dapat dipertanggungjawabkan kepada masyarakat.

5. Menjadikan instansi pemerintah yang akuntabel, sehingga dapat beroperasi secara efisien, efektif, dan responsif terhadap aspirasi masyarakat dan lingkungannya.

\section{Model Penelitian Dan Pengembangan Hipotesis}

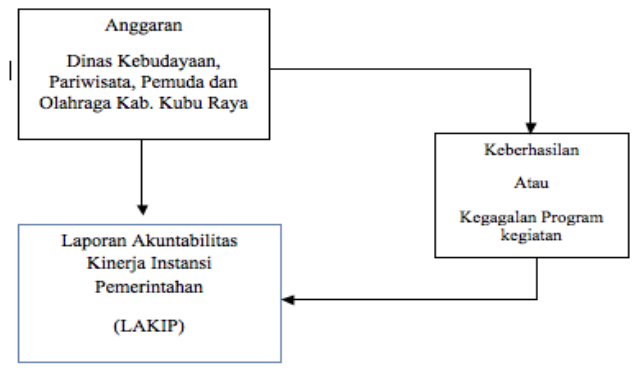

Gambar 1 Model Penelitian 


\section{Metode Penelitian}

\section{Jenis Penelitian}

Jenis penelitian yang digunakan adalah deskriptif yaitu, mengidentifikasi permasalahan "Analisis Laporan Akuntabilitas Kinerja Pada Dinas Kebudayaan, Pariwisata, Pemuda Dan Olahraga Kabupaten Kubu Raya" untuk dipecahkan, dengan metode yang digunakan adalah kualitatif yang bersumber dari Dinas Kebudayaan, Pariwisata, Pemuda dan Olahraga Kabupaten Kubu Raya.

\section{Sumber Data}

Sumber data penelitian ini adalah data sekunder yaitu, dengan cara mengumpulkan dokumen-dokumen terkait atau yang berhubungan dengan penelitian. Data sekunder di kumpulkan melalui studi pustaka (melalui jurnal, skripsi, dan data dokumentasi yaitu data laporan akuntabilitas kinerja instansi pemerintah dari Dinas Kebudayaan, Pariwisata, Pemuda dan Olahraga Kabupaten Kubu Raya).

\section{Teknik Pengumpulan Data}

Dalam penelitian ini metode pengumpulan data yang digunakan:

\section{Metode Dokumentasi}

Peneliti akan melakukan observasi langsung pada dokumen-dokumen terkait untuk mendukung penelitian yang dilakukan. Pada observasi penulis akan mengamati data-data yang diperlukan dalam penyusunan penelitian ini yang berkenaan dengan Laporan Akuntabilitas Kinerja Instansi Pemerintah (LAKIP) Dinas Kebudayaan, Pariwisata, Pemuda dan Olahraga Kabupaten Kubu Raya.

2. Media Elektronik

Metode pengumpulan data yang dilakukan lewat media elektronik berupa jaringan internet dengan melakukan penelusuran situs melalui alat bantu pencari seperti Google dan Jurnal-jurnal terkait.

\section{Alat Analisis}

Analisis data yang digunakan dalam penelitian ini melalui tahap-tahap sebagai berikut:

1. Menghitung rasio Kemandirian keuangan daerah berdasarkan APBD ( Abdul Halim: 2011)

Rasio Kemandirian=

$$
\frac{\text { Pendapatan asli daerah }}{\text { realisasi PAD }}
$$

2. Menghitung rasio efektifitas berdasarkan APBD

Rasio efektivitas $=$ Realisasi penerimaan pendapatan asli daerah Target penerimaan PAD yang ditetapkan

3. Menghitung rasio aktifitas terdiri dari:

a. Rasio belanja rutin terhadap APBD

$=$

Total belanja rutin terhadap $A P B D$

Total $A P B D$

b. Rasio belanja pembangunan terhadap APBD

$=\frac{\text { Total belanja pembangunan terhadap } A P B D}{}$ Total $A P B D$

4. Menghitung rasio pengelolaan belanja

Rasio pengelolaan belanja $=\frac{\text { Total pendapatan }}{\text { Total belanja }}$

5. Menghitung rasio pertumbuhan, yaitu dengan cara menghitung: 
a. Presentase pertumbuhan PAD

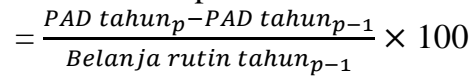

b. Presentase pertumbuhan total pendapatan

$=\frac{{\text { Pendapatan } \text { tahun }_{p}-\text { Pendapatan } \text { tahun }_{p-1}}_{\text {Pendapatan } \text { tahun }_{p-1}}}{100}$

c. Presentase pertumbuhan belanja rutin daerah

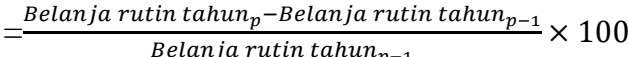

d. Presentase pertumbuhan belanja pembangunan

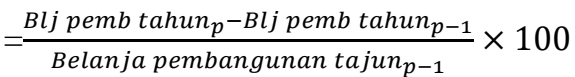

6. Membandingkan dan menganalisis rasio keuangan masing-masing periode yang telah di hitung berdasarkan perhitungan rasio keuangan pada tahap sebelumnya.

\section{Hasil Penelitian dan Pembahasan}

Berdasarkan pengolahan data, maka peneliti menemukan hasil sebagai berikut:

Rasio Kemandirian Keuangan Daerah Rasio kemandirian keuangan daerah menunjukkan kemampuan pemerintah daerah dalam membiayai sendiri kegiatan pemerintah dan pembangunan.

Rasio kemandirian $=\frac{\text { PendapatanAslidaerah }}{\text { RealisasiPAD }}$

Tabel 2

Kemandirian Keuangan Daerah Dinas BUDPARPORA

Kabupaten Kubu Raya

Tahun Anggaran 2011 s/d 2013

\begin{tabular}{|l|l|l|l|c|}
\hline No & Tabun & Total Rendapatan & Realisasi PAD & Kentribusi PAD \% \\
\hline 1 & 2011 & Rp 5.714.240.996 & RR 5.489.853.260 & 96,07 \\
\hline 2 & 2012 & Rp6.143. 562.447 & RR 5.977.737.230 & 97,30 \\
\hline 3 & 2013 & RR 6.310.961.650 & RR 5.872.680.313 & 93,05 \\
\hline & Jumlah & Rp18.168.765.093 & RR 17.340.270.803 & 95,44 \\
\hline & Rata-rata & RR 6.056.255.031 & RR 5.780.090.267 & 95,44 \\
\hline
\end{tabular}

Sumber: Dinas Kebudayaan, Pariwisata Pemuda dan Olahraga Kab. Kubu Raya

\section{Rasio Kemandirian Keuangan Daerah}

Rasio efektivitas menggambarkan kemampuan pemerintah daerah dalam merealisasikan pendapatan asli daerah yang direncanakan dibandingkan dengan target yang telah ditetapkan berdasarkan potensi riil daerah.

\section{Rasio Efektifitas = RealisasiPenerimaanPAD \\ TargetpenerimaanPADyangtelahditetapkan}

Tabel 3

Laporan Target dan Realisasi PAD Dinas BUDPARPORA Kabupaten Kubu Raya Tahun Anggaran 2011 s/d 2013

\begin{tabular}{|l|l|l|l|}
\hline Tabun & Target PAD & Realisasi PAD & Rasie efektifitas \% \\
\hline 2011 & RR 4.901.613.876 & RR 5.489.853.260 & 112 \\
\hline 2012 & RR 5.447.464.433 & RR 5.977.737.230 & 109,73 \\
& & & \\
\hline 2013 & RR 5.993.314.990 & RR 5.872.680.313 & 97,98 \\
\hline \multicolumn{2}{|l|}{ Rata-rata rasie efektifitas } & 106,57 \\
\hline
\end{tabular}

Sumber: Dinas Kebudayaan, Pariwisata Pemuda dan Olahraga Kab. Kubu Raya

\section{Rasio Aktifitas}

Rasio Aktifitas menggambarkan bagaimana pemerintah daerah dalam memprioritaskan alokasi dananya pada belanja rutin atau belanja pembangunan secara optimal. 
Rasio aktifitas dihitung sebagai berikut:

a. Rasio belanja rutin terhadap

$$
\mathrm{APBD}=\frac{\text { TotalbelanjaterhadapAPBD }}{\text { TotalAPBD }}
$$

b. Rasio belanja pembangunan terhadap APBD = Totalbelanjapembangunanterhadap $A P B D$ TotalAPBD

Tabel 4

Realisasi APBD Dinas BUDPARPORA Kabupaten Kubu Raya Tahun Anggaran 2011 s/d 2013

\begin{tabular}{|c|c|c|c|c|}
\hline No & Keterangan & 2011 & 2012 & 2013 \\
\hline \multirow[t]{2}{*}{\begin{tabular}{|l|}
1 \\
\end{tabular}} & Rendapatan APBD & Rp.5.714.240.996 & Rp 6.143.562.447 & Rp 6.310.961.650 \\
\hline & \begin{tabular}{|l|l} 
Jumlah pendapatan \\
\end{tabular} & Ap 5.714.240.996 & Rp.6.143.562.447 & Rp 6.310.961.650 \\
\hline \multirow{4}{*}{1} & Belanja & & & \\
\hline & Belania Rutin & Rpp 1.121.067.715 & Rp. 1.175.202.207 & RR 1.334.275.141 \\
\hline & Belanjia Pembangunan & Rp 4.368.785.545 & Rp 4.802 .505 .023 & RR 4.538.405.172 \\
\hline & Jumlah belanja & Rp.5.489.853.260 & Ap 5.977.707.230 & RR 5.872.680.313 \\
\hline
\end{tabular}

Sumber: Dinas Kébudayaan, Pariwisata Pemuda dan Olahraga Kabupaten Kubu Raya.

\section{Rasio Pengelolaan Belanja}

Rasio pengelolaan belanja menunjukkan bahwa kegiatan belanja yang dilakukan oleh pemerintah daerah memiliki ekuitas antar periode yang positif, yaitu belanja yang dilakukan tidak lebih besar dari total pendapatan yang diterima oleh pemerintah daerah. Rasio ini menunjukkan adanya surplus/defisit anggaran.

Rasio pengelolaan belanja $=\frac{\text { Total pendapatan }}{\text { Total belanja }}$
Tabel 5

Laporan Surplus/Defisit

Anggaran Dinas

BUDPARPORA

Kabupaten Kubu Raya

Tahun Anggaran 2011 s/d 2013

\begin{tabular}{|l|l|l|l|}
\hline Tabun & Rendapatan & Belania & Surplus/defisit \\
\hline 2011 & RR 5.714.240.996 & RR 5.489.853.260 & RR 224.387.739 \\
\hline 2012 & RR 6.143.562.447 & RR 5.977.707.230 & RR 165. 855.217 \\
\hline 2013 & RR 6.310.961.650 & RR 5.872.680.313 & RR 438. 281.337 \\
\hline
\end{tabular}

Sumber: Dinas Kebudayaan, Pariwisata Pemuda dan Olahraga Kabupaten Kubu Raya.

\section{Rasio Pertumbuhan}

Rasio pertumbuhan menunjukkan seberapa besar kemampuan pemerintah daerah dalam mempertahankan dan meningkatkan keberhasilannya yang telah dicapai dari periode ke periode.

a. Presentase pertumbuhan PAD

$$
=\frac{P A D \operatorname{tahun}_{p}-P A D \operatorname{tahun}_{p-1}}{{\text { Belanja rutin } \text { tahun }_{p-1}}_{10}} \times 100
$$

b. Presentase pertumbuhan total pendapatan

$$
=
$$

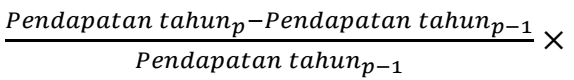

100

c. Presentase pertumbuhan belanja rutin daerah

$=$

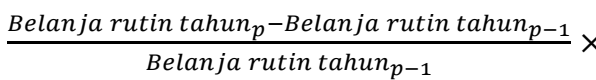

100

d. Presentase pertumbuhan belanja pembangunan

$=\frac{{\text { Blj pemb } \text { tahun }_{p}-\text { Blj pemb } \text { tahun }_{p-1}}_{\text {Belanja pembangunan tahun }}-1}{100}$ 100 
Tabel 6

Rasio Pertumbuhan APBD Dinas BUDPARPORA Kabupaten Kubu Raya Tahun Anggaran 2011 s/d 2013

\begin{tabular}{|c|c|c|c|c|}
\hline No & Keterangan & 2011 & 2012 & 2013 \\
\hline \begin{tabular}{|l|}
1 \\
\end{tabular} & PAD & Rp 5.714.240.996 & \begin{tabular}{|l|l} 
Rp 6.143.562.447 \\
\end{tabular} & RR 6. 310.961.650 \\
\hline 2 & Bertumbuhan PAD & - & $7,51 \%$ & $7,51 \%$ \\
\hline 3 & \begin{tabular}{|l|} 
Total pendapatan \\
\end{tabular} & Rp 5.714.240.996 & Rp 6.143.562.447 & \begin{tabular}{|l} 
Rp 6. 310.961.650 \\
\end{tabular} \\
\hline 4 & $\begin{array}{l}\text { Rertumbuhan } \\
\text { pendapatan }\end{array}$ & . & $7,51 \%$ & $7,51 \%$ \\
\hline 5 & Belanja Rutin & Rp. 1.121.067.715 & Rp 1.175.202.207 & \begin{tabular}{|l|} 
RR 1.334.275.141 \\
\end{tabular} \\
\hline 6 & $\begin{array}{l}\text { Rertumbuhan belanja } \\
\text { rutin }\end{array}$ & . & $4,82 \%$ & $13,53 \%$ \\
\hline 7 & Belania pembangunan & Rp 4.368.785.545 & Rp 4.802.505.023 & RR 4.538.405.172 \\
\hline 8 & $\begin{array}{l}\text { Pertumbuhan belanja } \\
\text { pembangunan }\end{array}$ & - & $9,92 \%$ & $-5,49 \%$ \\
\hline
\end{tabular}

Sumber: Dinas Kebudayaan, Pariwisata Pemuda dan Olahraga Kabupaten Kubu Raya.

\section{Pembahasan}

\section{Rasio Kemandirian Keuangan Daerah}

Berdasarkan perhitungan rasio kemandirian keuangan diatas bahwa kemampuan pemerintah daerah dalam membiayai sendiri kegiatan pemerintahan, pembangunan dan pelayanan masyarakat pada tahun anggaran $2011 \mathrm{~s} / \mathrm{d} 2013$ sangat baik dengan rata-rata $95,44 \%$ hampir mencapai $100 \%$, yaitu pada tahun 2011 sebesar 96,07\%, pada tahun 2012 sebesar 97,30\%, dan tahun 2013 sebesar 93,05\%. Kinerja pengelolaan keuangan Dinas Budparpora Kabupaten Kubu Raya sangat baik meskipun pada tahun 2013 mengalami sedikit penurunan dari $97,30 \%$ menjadi 93,05\% atau $4,25 \%$ dari tahun 2012, namun pada tahun 2011 mengalami kenaikan dari $96,07 \%$ menjadi $97,30 \%$ atau mengalami kenaikan sebesar $1,23 \%$.

Kenaikan rasio kemandirian keuangan pada tahun 2012 disebabkan karena pendapatan yang bertambah dari $\mathrm{Rp}$ 5.714.240.996 menjadi Rp 6.143.562.447 atau mengalami kenaikan pendapatan sebesar Rp 429.321.451, kenaikan pendapatan ini disebabkan karena tingkat capaian kinerja dalam rangka mewujudkan visi dan misi Dinas Kebudayaan, Pariwiwsata, Pemuda dan Olahraga
Kabupaten Kubu Raya dicapai dengan kategori sangat berhasil.

\section{Rasio Efektifitas}

Dari perhitungan rasio efektifitas dapat dilihat bahwa efektifitas pengelolaan keuangan Dinas Budparpora cukup baik karena realisasi PAD diatas $100 \%$, yaitu rata-rata dari tahun 2011 S/D 2013 sebesar $106,57 \%$. Sedangkan pada tahun 2013 kurang baik karena realisasinya di bawah dari target yang telah ditetapkan yaitu sebesar $97,98 \%$. Penurunan realisasi pada tahun 2013 disebabkan oleh beberapa target indikator kinerja yang meningkat namun tidak diiringi dengan realisasi yang meningkat bahkan cenderung mengalami sedikit penurunan.

\section{Rasio Aktifitas}

Dari perhitungan rasio aktifitas diatas terlihat bahwa sebagian besar dana dialokasikan untuk belanja pembangunan sehingga rasio belanja rutin terhadap APBD masih sangat rendah. Rasio belanja rutin pada tahun 2011 adalah $19,61 \%$ dan rasio pembangunan sebesar $76,45 \%$, pada tahun 2012 rasio belanja rutin turun menjadi $19,12 \%$ dan rasio belanja pembangunan naik menjadi $78,17 \%$, rasio belanja rutin pada tahun 2013 naik menjadi $21,14 \%$ dan rasio belanja pembangunan turun menjadi $71,91 \%$.

Sehingga dapat disimpulkan bahwa berdasarkan rasio aktifitas Dinas Budparpora Kabupaten Kubu Raya lebih memprioritaskan belanjanya pada belanja pembangunan dari pada belanja rutin.

\section{Rasio Pengelolaan Belanja}

Dari perhitungan rasio pengelolaan belanja diatas dapat dilihat bahwa kinerja pengelolaan belanja semua mencapai angka diatas $100 \%$. Dapat dilihat bahwa kinerja pengelolaan belanja yang paling baik adalah pada tahun 2013 yaitu $107,46 \%$ yang menunjukkan surplus sebesar Rp 438. 281.337, dibanding tahun sebelumnya yang mengalami surplus anggaran lebih kecil 
yaitu pada tahun 2011 sebesar Rp 224.387.739 dan pada tahun 2012 sebesar Rp 438. 281.337. Ini bisa disebabkan karena pada tahun 2013 pendapatan bertambah dari tahun sebelumnya namun realisasinya menurun dari tahun sebelumnya sehingga surplus yang didapat menjadi lebih besar dibandingkan pada tahun sebelumnya yakni 2011 dan 2012 pendapatan yang didapat memang mengalami penambahan namun diikuti juga dengan realisasi yang juga ikut bertambah maka, surplus dialami juga kecil.

\section{Rasio Pertumbuhan}

Dari perhitungan diatas dapat diketahui bahwa pertumbuhan APBD Dinas Kebudayaan, Pariwisata, Pemuda dan Olahraga (BUDPARPORA) Kabupaten Kubu Raya pada tahun 2011 s/d 2013 menunjukkan pertumbuhan yang positif. Karena, pertumbuhan pendapatan pada tahun 2012 hingga tahun 2013 menunjukkan angka yang sama yakni sebesar 7,51\% dan pendapatan utama Dinas Budparpora hanya bersumber dari APBD tidak ada bantuan dari pemerintah Pusat atau Provinsi.

Selain pendapatan, belanja Dinas Budparpora Kabupaten Kubu Raya yang terdiri dari belanja rutin dan belanja pembangunan juga mengalami pertumbuhan. Belanja rutin pada tahun 2012 sebesar 4,82\% dan mengalami peningkatan pada tahun 2013 yakni sebesar 13,53\%. Pada pos belanja Pembangunan pertumbuhannya pada tahun 2012 sebesar $9,92 \%$ tetapi pertumbuhan belanja pembangunan mengalami penurunan pada tahun 2013 yakni sebesar $-5,49 \%$. Ini disebabkan karena pos belanja pembangunan pada tahun 2013 dananya lebih dialihkan kepada pos belanja rutin sehingga pos belanja pembangunan realisasinya lebih rendah dari tahun 2012 yakni penurunannya sebesar Rp 264.099.851 dari tahun 2012.

\section{Simpulan dan Saran}

\section{Simpulan}

a. Berdasarkan rasio kemandirian keuangan Dinas BUDPARPORA Kabupaten Kubu Raya sudah memiliki kemampuan untuk membiayai sendiri seluruh kegiatan yang telah dijadwalkan dengan rata-rata perolehan sebesar $95,44 \%$ atau sudah mencapai angka diatas $90 \%$. Dengan pendapatan yang didapat kemampuan Dinas BUDPARPORA untuk merealisasikan semua program yang telah menjadi sasaran strategis dapat di jalankan dengan baik.

b. Berdasarkan rasio efektifitas kemampuan Dinas BUDPARPORA dalam merealisasikan target-target yang telah disepakati juga sangat baik karena presentase rata-rata-nya sudah melebihi dari $100 \%$ yakni sebesar 106,57\%.

c. Berdasarkan rasio aktifitas yang terbagi atas 2 (dua) bagian yakni pos belanja rutin dan pos belanja pembangunan. Dinas BUDPARPORA lebih mengalokasikan dananya pada pos belanja pembangunan sehingga pos belanja rutin masih rendah. Rata-rata alokasi pada belanja rutin hanya mencapai $19,95 \%$ dan pada alokasi dan belanja pembangunan rata-ratanya mencapai $75,51 \%$ atau diatas $70 \%$.

d. Berdasar rasio pengelolaan belanja Dinas BUDPARPORA Kabupaten Kubu Raya tahun 2011-2013 seluruh pengelolaan belanjanya mencapai angka diatas 100\% dan juga mengalami surplus pendapatan. Pengelolaan belanja paling baik dan presentase nya paling tinggi terdapat pada tahun 
2013 yakni mencapai 107,46\% dan surplus sebesar Rp 438.281.337,00. Hal ini menunjukkan bahwa Dinas BUDPARPORA Kabupaten Kubu Raya sudah sangat baik dalam merealisasikan anggaran belanja yang didapatkan.

e. Berdasarkan rasio pertumbuhan APBD Dinas BUDPARPORA rata-rata mengalami pertumbuhan yang positif. Pertumbuhan tahun 2011-2013 ada yang mengalami peningkatan, ada yang tetap bahkan ada yang mengalami penurunan. Tetapi pertumbuhan pengelolaan keuangan Dinas BUDPARPORA Kabupaten Kubu Raya sudah sangat baik dan menunjukkan pertumbuhan yang positif.

\section{Saran}

Berdasarkan hasil penelitian, peneliti mengungkapkan saran sebagai berikut:

a. Penetapan indikator-indikator kinerja yang menjadi tolak ukur keberhasilan/kegagalan perlu diperhatikan. Indikator kinerja harus dapat terukur dengan jelas misalnya jumlah kegiatan yang dilaksanakan, jumlah pegawai yang mengikuti bimbingan teknis, dan sebagainya sehingga dapat dilihat capaian kinerja apakah sesuai dengan yang direncanakan atau tidak.

b. Pemerintah perlu menetapkan acuan yang bersifat baku dalam penyusunan Laporan Akuntabilitas Kinerja Instansi Pemerintahan (LAKIP).

\section{Daftar Pustaka}

Bastian, Indra. 2007. Audit Sektor Publik. Erlangga. Jakarta.
Benveniste, Guy, Birokrasi, Jakarta : Rajawali, 1991. • INDONESIA

Halim, Abdul. 2012. Akuntansi Sektor Publik, Keuangan Daerah. Penerbit Salemba Empat. Jakarta.

Laporan Akuntabilitas Kinerja Dinas Pariwisata Pemuda Dan Olahraga Kabupaten Kubu Raya. 2011. Kab. Kubu Raya.

Laporan Akuntabilitas Kinerja Dinas Pariwisata Pemuda Dan Olahraga Kabupaten Kubu Raya. 2012. Kab. Kubu Raya.

Laporan Akuntabilitas Kinerja Dinas Pariwisata Pemuda Dan Olahraga Kabupaten Kubu Raya. 2013. Kab. Kubu Raya.

L. Mathis Robert and John H.Jackson. 2011. Manajemen Sumber Daya Manusia. Edisi 10. Jakarta : Salemba Empat.

Mangkunegara, Anwar Prabu. 2013. Manajemen Sumber Daya Manusia Perusahaan. Bandung : PT Remaja Rosdakarya.

Mangkunegara Anwar Prabu, 2005. Evaluasi Kinerja SDM, Bandung: PT. Refika Aditama.

Mardiasmo. 2011. Akuntansi Sektor publik. Yogyakarta: Andi.

Mardiasmo, "Telaah Kritis terhadap Kebutuhan Pengukuran Kinerja Pemerintah Daerah". Jurnal Unisia. No.46/XXV/III/2002.

Nordiawan, Deddi. 2010. Akuntansi Sektor Publik. Salemba Empat. Jakarta.

Notoatmojo, Loc.Cit.Peraturan Menteri Pendayagunaan Aparatur Negara Nomor 29 Tahun 2010 tentang Pedoman Penyusunan

Penetapan Kinerja dan Pelaporan Akuntabilitas Instansi Pemerintah. Pemerintahan. Alfabeta. Bandung

Rakhmat.2013. Reformasi Birokrasi Publik Dalam Perspektif Good Governance. Jurnal Paradigma, Vol 2 No.1, April 2013: 1-9.

Santoso, Susan. 2013. Analisis Laporan Akuntabilitas Kinerja Pada Dinas 
Jurnal Akuntansi Maranathaø Volume 11 Nomor 2, November 2019 : 276-288

Kebudayaan Dan Pariwisata Provinsi Sulawesi utara. Manado.

Teguh Ambar dan Rosidah, 2003.

Manajemen Sumber Daya

Manusia, Graha Ilmu: Yogyakarta. 